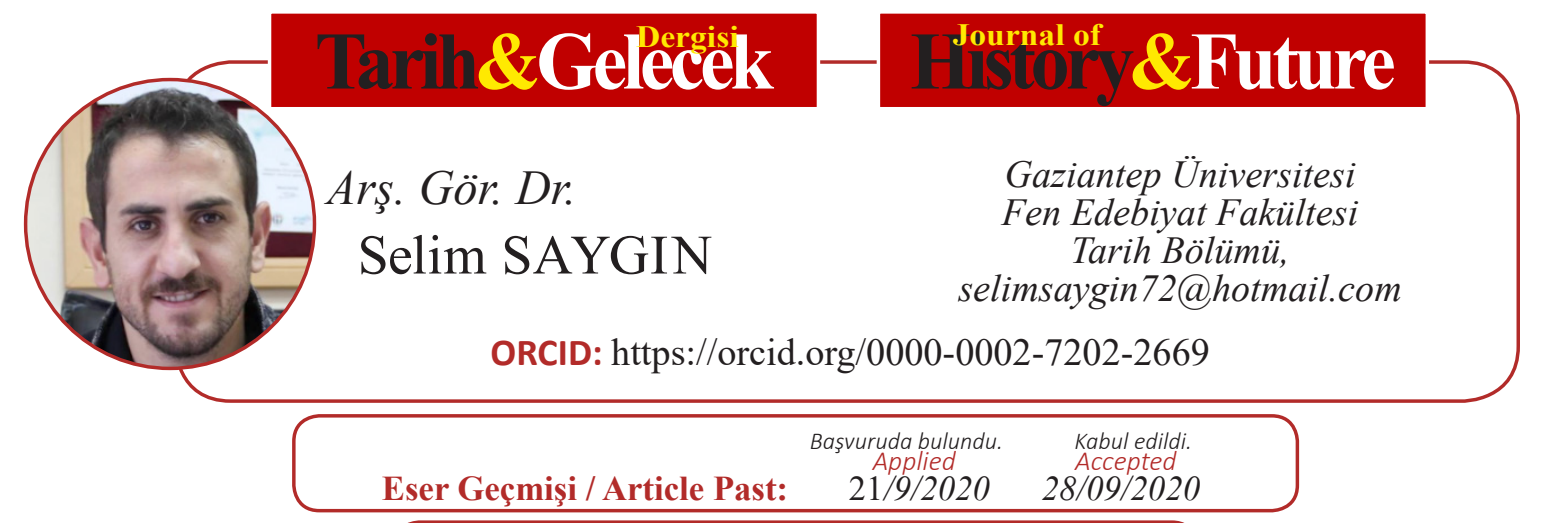

DOI: http://dx.doi.org/10.21551/jhf.798079

Research Paper

Orjinal Makale / Orginal Paper

\title{
Kâzım Karabekir ve Terakkiperver Cumhuriyet Fırkası
}

\author{
Kâzım Karabekir and Progressive Republican Party
}

\section{$\ddot{O} z$}

Osmanlı Devleti'nin son dönemlerde yetiştirdiği önemli subaylarından biri ve Milli Mücadele'nin de en büyük kahramanlarından olan Kâzım Karabekir, 1882 yılında İstanbul'da dünyaya gelmiştir. 1900 yılında Kuleli Askeri Lisesi'nden mezun olan Karabekir, daha sonra 1903 yılında Erkan-1 Harp Mektebi'ne, başlamıştır. 1905 yılında sınıf birincisi olarak Harp Akademisi'ni bitirdikten sonra 1906 yılında Manastır'da önyüzbaşı olarak görevine başlamıştır. Kuleli Askeri Lisesindeyken tanıştığı Mustafa Kemal önderliğindeki Kurtuluş Savaşı'na önemli katkıları olmuş, ancak zaferden sonra gerçekleşen inkılâplarda gerek kendi görüşünün alınmaması, gerekse de bazı inkılâplara düşünsel anlamda karşı çıkması Atatürk ile arasının açılmasına neden olmuştur. 17 Kasım 1924 yılında Atatürk'e ve hükümete muhalif olarak kurulan, Cumhuriyet tarihinin ilk teşkilatlı muhalefeti Terakkiperver Cumhuriyet Fırkası'nın liderliğini yapmıştır. Partisi adına mecliste en çok söz alan ikinci milletvekili olmuş, eğitim, ekonomi ve askeri alanlarda fikirlerini birçok kez dile getirmiştir. Basın organlarında birçok yerde partisini tanıtmış ve savunmuş, ülkenin geleceği için fikirlerinin açıklamaktan çekinmemiştir. Takrir-i Sükûn Kanunu ile partisinin kapatılmasını sert bir şekilde eleştirmiş, bunu tarihi bir hata olarak görmüştür.

Anahtar Kelimeler: Kâzım Karabekir, Terakkiperver Cumhuriyet Fırkası, TBMM, Milli Mücadele, Mustafa Kemal Atatürk, İttihat ve Terakki Cemiyeti

\section{Abstract}

Kâzım Karabekir, who one of the most important officers of the Ottoman Empire recently trained and one of the greatest heroes of the National Struggle, was born in Istanbul in 1882. In 1900, after he graduated from Kuleli Military School, he went toErkan Military School in 1903. In 1905, he graduated from Military Academy as a top of his class and started his military life in 1906 at Manastir as a senior captain. He made important contributions to the War of Independence led by Mustafa Kemal, whom he met at Kuleli Military High School. However, in the revolutions that took place after the victory, his own opinion was not taken and his opposition to some reforms in a intellectual sense caused his disagreement with Atatürk. On the 17th November 1924, he became leader Progressive Republican Party which is the first opposition organization of republican history and was founded to be opposition against Ataturk and the government. He was the second most MP to speak on behalf of his party, he has expressed his opinions many times in the fields of education, economy and military. He promoted and defended his party in many places in the media and did not hesitate to express his ideas for the future of the country. He sharply criticized the closure of his party with the Takrir-i Sükûn Law and saw this as a historical mistake.

Key Words: Kâzım Karabekir, Progressive Republican Party, Grand National Assembly of Turkey, Committee of Union and Progress, National Struggle, Mustafa Kemal Atatürk

\section{* Bu makalede, "Kâzım Karabekir'in Terakkiperver Cumhuriyet Fırkasındaki Faaliyetleri”" adlı yüksek lisans tezimden üretilmiştir.}

ATIF: SAYGIN Selim , "Kâzım Karabekir ve Terakkiperver Cumhuriyet Fırkası", Tarih ve Gelecek Dergisi, 6/3 (Eylül 2020), s. (1091-1108)

CITE: SAYGIN Selim, "Kâzım Karabekir and Progressive Republican Party ", Journal of History and Future, 6/3 (September 2020), pp. (1091-1108) 


\section{Giriş}

1

9. yüzyılın sonları ile 20. yüzyılın başları hem Dünya tarihi açısından hem de Osmanlı Devleti açısından bir hayli karmaşık önemli olayların yaşandığı bir dönem olarak karşımıza çıkmaktadır. 1789 yılındaki Fransız ihtilalinin getirdiği milliyetçi dalga dünyada yeni bir düzenin kurulmasını sağlamış ve milliyetçilik esasına dayalı yeni devletlerin kurulmasını sağlamıştır. Bünyesinde birçok ulusu barındıran ve bu özeliği ile imparatorluk vasfina sahip olan Osmanlı İmparatorluğu, AvusturyaMacaristan ile birlikte bu kozmopolit yapısından dolayı milliyetçi akımlardan en çok etkilenen devletlerden biri olmuştur.

Avrupa ve Balkanlarda artan milliyetçiliğin de etkisiyle Osmanlı Devleti bünyesinde bulunan birçok ulus bağımsızlık mücadelesi vermiş ve birçoğu da amacına ulaşmıştır. Tabi bu artan Milliyetçilik dalgası Osmanlı aydınlarını da etkilemiş ve Türklük bilinci hem aydınlar hem de devlet bürokrasisinde etkisini göstermiştir. İlk etapta Jön Türkler adıyla anılan bu hareket daha sonra İttihat ve Terakki Cemiyeti adı altında örgütlenmiş, II. Abdülhamit'e meşrutiyeti kabul ettirip Osmanlı Devleti'nde rejim değişikliğini sağlamıştır. Bu cemiyet, bünyesinde daha sonra Kuruluş Savaşını başlatacak ve Osmanlı Devletinin küllerinden yeni bir devleti kuracak subayları da barındırıyordu. Bunlar arsında Mustafa Kemal, Kâzım Karabekir, İsmet İnönü, Rauf Orbay, Fethi Okyar ve Refet Bele gibi Kurtuluş Savaşının önemli kahramanları vardı.

20. Yüzyılın başlarına gelindiğinde Dünya, İtilaf ve İttifak devletleri olarak iki kutba ayrılmış ve büyük bir savaş artık kaçınılmaz hale gelmişti. 1914 yılında Avusturya-Macaristan'ın Sırbistan'a savaş ilan etmesiyle başlayan ve dört yıl boyunca dünyayı kasıp kavuracak olan I. Dünya harbinin fitili ateşlenmişti. Osmanlı Devleti, bu savaşta başlarda tarafsız bir politika gütmeye çalışsa da Almanya'nın yanında, İttifak devletleri safında savaşa girmek zorunda kalmıştır.

Osmanlı Devleti’nin I. Dünya Savaşında yenik düşmesi, İmparatorluk topraklarının dağılması Anadolu'nun işgalini de beraberinde getirmiştir. Bu işgallere karşı Mustafa Kemal Paşa önderliğinde Anadolu'da kurtuluş mücadelesi başlamıştır. Bu kurtuluş mücadelesinin içinde ve yeni devletin öncü kurucu kadroları içinde Kâzım Karabekir de yer almaktadır.

Kâzım Karabekir, Osmanlı Devletinin Anadolu'da dağıtılmamış olan en büyük ordusu olan 15. Kolordunun komutanıydı. Kurtuluş Savaşı boyunca Atatürk'ün en yakınındakilerden ve en büyük destekçilerden biri olmuştur. Doğu Anadolu'da Ermeniler ile girişilen savaştan zaferle ayrılmış, Gümrü Antlaşmasıyla Doğu sınırımızı güvence altına alarak Batı cephesine önemli desteklerde bulunmuştur.

Kâzım Karabekir yeni devletin kuruluşunda da fikri ve fiili katkılarda da bulunmuştur. Ancak kurucu kadro içindeki birliktelik çok uzun sürmemiş ve görüş ayrılıkları ortaya çıkmaya başlamıştır. Yaşanan bu görüş ayrılıkları Cumhuriyetin kuruluşundan itibaren daha da derinleşmiş ve Terakkiperver Cumhuriyet Fırkasının kuruluşuna neden olmuştur. Kurulan bu yeni partinin başına da Kâzım Karabekir geçmiştir. Yaklaşık yedi ay varlığını sürdüren Terakkiperver Cumhuriyet Fırkasının liderliğini Doğu Cephesi Komutanı Kâzım Karabekir yapmıştır. Şeyh Sait ayaklanması, Terakkiperver Cumhuriyet Fırkasının kapatılma sürecini hazırlamış ve çıkarılan Takrir-i Sükûn yasası ile Terakkiperver Cumhuriyet Fırkası kapatılmıştır. Kâzım Karabekir Paşa ve Terakkiperver Cumhuriyet Fırkasının önde gelen isimleri İstiklal Mahkemelerinde yargılanmıştır. İstiklal Mahkemesinde yargılanan Karabekir Paşa, davadan beraat etmiş ancak bundan sonra kendisi açısından zor dönem başlamıştır. 1938 yılına kadar da tecrit altında tutulmuş ve daha sonra meclis başkanlığı da yapmıştır. 


\section{Kâzım Karabekir'in Hayatı}

1882 yılında İstanbul'un Küçük Mustafa Paşa Semtinde dünyaya gelen Karabekir'in doğum tarihi hakkında net bir tarih verilememektedir. ${ }^{1}$ Karabekir, "Hayatım" adlı eserinde doğum tarihini 11 Ağustos 1298 tarihi olarak açıklarken; Karabekir hakkında bir biyografi çalışmasında bulunan Fahrettin Kirzıoğlu ise bu tarihi 11 Temmuz 1298 olarak ifade etmektedir. ${ }^{2}$

Kâzım Karabekir'in eğitim yaşamı 1885 'te üç yaşında iken başlamıştır. ${ }^{3}$ Üç yaşındayken Zeyrek’te başladığı Sıbyan Mektebini Van'da tamamlamıştır. Babasının ölümü üzerine İstanbul'a döndükten sonra Ortaöğrenimini İstanbul Fatih Askeri Rüştiyesinde tamamlamıştır. 1896 yılında Kuleli Askeri İdadisi'ne başlayan Karabekir'de Türklük bilinci bu dönemde oluşmaya başlamıştır. ${ }^{4}$ Kuleli Askeri İdadisini bitirdikten sonra 1900 y1lında İstanbul Harp Okulunda harbiye eğitimine başlamış ve Harbiyeyi sınıf birincisi olarak bitirmiştir. 1903 yılında Harp Okulundan sınıf birincisi olarak mezun olduktan sonra yine aynı yıl Harp Akademisine (Erkan-1 Harbiye) başlamış ve burada kurmay eğitimi almaya başlamıştır. ${ }^{5}$

1903-1905 yılları arasında Harp Akademisinde eğitim gören Karabekir, burada ağabeyi Hamdi Bey aracılığıyla İttihat ve Terakki Partisi ile tanışmıştır. ${ }^{6}$ Harp Akademisi'nden 5 Kasım 1905 tarihinde sınıf birinciliği ile ve kurmay yüzbaşı olarak mezun olmuş ve ilk görev yeri olarak ta Manastır çıkmıştır. ${ }^{7}$ Manastır'daki stajını bitirdikten sonra 6 Eylül 1906 tarihinde İstanbul'daki Pangaltı Harbiye Mektebine görevlendirilmiş, Burada Tabiye (Askeri Strateji) olarak göreve başlamıştır. İstanbul'a geldikten sonra İttihat ve Terakki Cemiyeti'nin Harbiye'deki yapılanmasında aktif olarak rol almıştır. Karabekir İttihat ve Terakki Cemiyeti adlı kitabında İstanbul'daki fedai cemiyetini kendisi kurduğunu ve kendisinin de bir fedai olduğundan bahseder. ${ }^{8}$

Meşrutiyetin ilanından sonra gelen özgürlükçü ortamın yaşamı kısa sürmüştür. 8 ay kadar süren bu ortam 31 Mart 1325(13 Nisan 1909) y1lında İstanbul'da ortaya ayaklanma ile son bulmuştur. Bu ayaklanma İttihat ve Terakki Cemiyetinin düzeni sağlama konusundaki yetersizliğini de gözler önüne sermiştir. Kâzım Karabekir bu arada Edirne'de bulunan 2. Orduda 3. Tümene kurmay başkanı olarak atanmıştır. ${ }^{9}$

Kâzım Karabekir, 27 Nisan 1912 yılında binbaşılığa yükseldikten kısa bir süre sonra Balkan Savaşı patlak verir. Bu sırada kendisi Edirne Kalesi'ndedir. Edirne'nin uzun süreli direnişinde Müstahkem Mevkiindeki 10. Tümenin Kurmay Başkanıdır. Uzun süren direnişte açlık ve cephane kalmamasından dolayı direniş kırılır ve 22 Nisan 1913 yılında Edirne Bulgarlara geçerken kendisi de Bulgarlara esir düşerek Sofya'ya gönderilir. İkinci Balkan Savaşında Edirne geri alındıktan sonra 29 Eylül 1913 yılında Bulgaristan ile imzalanan İstanbul Antlaşması gereğince beş ay süren esareti biter ve İstanbul'a gelir. ${ }^{10}$

1

Kâzım Karabekir, Hayatım, 1. bask1, Tarih (İstanbul: Yapı Kredi Yayınları, 2014), 27.

Karabekir, Hayatım, 27; Kâzım Karabekir ve M. Fahrettin Kırzıŏlu, Kâzım Karabekir: kendi eserleri, haltercümeleri ve Arşiv Belgeleri’ne göre, Kültür Bakanlığı yayınları; Türk büyükleri dizisi, 1278. 135 (Ankara: Kültür Bakanlığı, 1991 ), 7.

3 Ali Çiftçi, “Kâzım Karabekir'in Siyasal Hayatı" (Doktora Tezi, Ankara, Ankara Üniversitesi Sosyal Bilimler Enstitüsü Kamu Yönetimi Anabilim Dal1, 2005), 28.

Kırzıoğlu, Kâzım Karabekir, 8.

Karabekir, Hayatım, 137.

Çiftçi, “Kâzım Karabekir'in Siyasal Hayatı”, 10.

Karabekir, Hayatım, 184.

Kâzım Karabekir, Ittihat ve Terakki Cemiyeti, 1. bask1, Tarih 48 (İstanbul: YKY, 2014), 163.

Feroz Ahmad, Ittihat ve Terakki: 1908 - 1914, 4. basım, Kaynak Yayınları (İstanbul: Kaynak Yayınları, 2004$), 67$.

Kâzım Karabekir, Bulgaristan Esareti ve Hatıralar Notlar, Tarih (İstanbul: Emre Yayınları, 2003), 25. 
Avusturya- Macaristan'ın Sırbistan'a savaş açması ile Birinci Dünya Savaşında. ${ }^{11}$ Kâzım Karabekir'in ilk görevi 8 Ocak 1915 tarihinde İran Harekâtına memur olarak atanması olmuştur. Ancak daha sonra yapılan değişiklikle İstanbul Kartal 14. Tümen Komutanlığına görevlendirilir ve buradaki görevi de Marmara ve Karadeniz kıyılarındaki tahkimat işleri olmuştur. Kâzım Karabekir, İstanbul'daki görevinden sonra tümeni ile beraber Çanakkale savaşında görevlendirilir. Çanakkale Cephesinde Kereviz Dere'de üç buçuk ay boyunca Fransızlar ile çarpışır. Karabekir'in Kerevizdere' de Fransızlara karşı sürdürdüğü başarılı mücadele üzerine kendisine Muharebe Gümüş Liyakat Madalyası ve Harp Madalyası verilmiştir. Kâzım Karabekir'in Gelibolu Muharebelerinde gösterdiği yararlılıklar üzerine 14 Aralık 1915 yılında kendisine Miralay(Albay) rütbesi verilmiştir. Kâzım Karabekir, 26 Ekim 1915 tarihinde 1. Ordu Kurmay Başkanlığına Tayin edilir. Ancak Çanakkale Cephesi Komutanı Limon von Sanders kurmay başkanlığına daha kıdemli albayların getirilmesini öne sürerek buna itiraz etmiş ve Galiçya Cephesine gidecek olan ordunun kurmay başkanlığına atanmıştır. Daha sonra bu görev de değiştirilmiş, 10 Kasım 1915 yılında Irak Cephesinde savaşan 6. Ordu komutanı Von der Goltz Paşanın yanında kurmay başkanlığına getirilmiştir. ${ }^{12}$ Daha sonra 1917 yılında Liceye Kafkas cephesine nakledilen Karabekir Paşa, ardından 3. Ordu Komutanı Vehip Paşa'nın isteği üzerine karargâh merkezini Refahiye'de bulunan 3. Orduya naklettirmiş ve 28 Ocak 1918 yılında 1. Kafkas Kolordusu Komutanlığına tayin edilmiştir. ${ }^{13}$

Kâzım Karabekir, 1918 yılı içerisinde askeri açıdan birçok başarı kaydetmiştir. 1877 yılında Ruslar ile yapılan meşhur Doksan Üç Harbinde Ruslara kaptırılan ve yaklaşık kırk yıldır da Rus egemenliğinde bulunan Sarıkamış ve Kars'1 Ruslardan kurtaran 3. Orduda 1. Kafkas Kolordu komutanı idi. ${ }^{14}$ Ruslar ile yapılan Brest Litovsk anlaşması ile bu sınırları güvenceye aldıktan sonra Ermenilere karşı harekete geçmiş ve Gümrü’yü Ermenilerden teslim almıştır. $\mathrm{Bu}$ gelişmeler karşısında zor durumda kalan Ermenistan hükümetini 14 Haziran 1918 tarihinde Batum Antlaşmasını kabul ettirmek zorunda bırakmıştır. ${ }^{15}$ Bununla da yetinmeyen Karabekir Paşa, İngilizlere karşı da harekete geçerek Tebriz'i ele geçirmiş, ancak Filistin cephesinden gelen bozgun haberleri neticesinde karargâhını Nahcivan'a taşımak zorunda kalmıştır. ${ }^{16}$

Tarihler, 30 Ekim 1918'i gösterdiğinde Osmanlı Devleti, Mondros Mütarekesini imzalamak durumunda kalmıştır. Mütarekenin imzalanması üzerine Karabekir'e kolordusunun lağvedildiği ve İstanbul'a dönmesi emri gelmiştir. Mütareke gereği Osmanlı birlikleri 1914 sınırlarına çekilmek zorunda kalmıştır. ${ }^{17}$

\section{I.I. Milli Mücadelede Kâzım Karabekir}

Kâzım Karabekir, 28 Kasım 1918 tarihinde İstanbul'a gelip Boğaz'da İngiliz ve Fransız gemilerini gördüğünde "tek dă̆başı mezar oluncaya kadar uğraşmalı"18 diyerek kurtuluş mücadelesi için o gün ant içtiğini belirtmektedir. Bu maksatla İstanbul'daki ilk görüşmesini ağabeyinin evinde Albay İsmet Paşa ile gerçekleştirdiğini söylemektedir. Bu görüşmede Karabekir, İsmet Bey’e genç

11 Norman Stone, Birinci dünya savaşı (İstanbul: Doğan Kitap, 2010), 35.

12 Kırzıoğlu, Kâzım Karabekir, 14-15.

13 Kazım Çavdar, Kâzım Karabekir (İzmir: Sobe Matbaası, t.y.), 46.

14 Bolşevik Devrimi olduğundan Sarıkamış ve Kars, 18 Aralık 1917 yılında imzalanan Erzincan Antlaşmasında Rus Ordusundan geriye kalan yerli Ermeni milislerden alınmıştır. Çiftçi, "Kâzım Karabekir'in Siyasal Hayatı”, 28.

15 Kazım Karabekir, Birinci cihan harbini nasıl idare ettik?: Sarıkamış, Kars ve ötesi (İstanbul: Emre, 1994), $297-301$.

16 Mukaddes Arslan, “MILLİ MÜCADELE’DE KAZIM KARABEKİR PAŞA”, 2012, 118.

17 Yunus Emre Tansü, “KAZİM KARABEKİR'IN DİPLOMAT KİŞİİĞİ”, Social Sciences Studies Journal 4, sy 25 (01 Ocak 2018): 5450.

18 Kâzım Karabekir, İstiklâl Harbimiz, c. 1 (İstanbul: Emre Yayınları, 2003), 84-87. 
komutanların Anadolu'ya görevlerinin başına dönmeleri ve kendisinin de Doğu'ya tekrar tayin edilmesi gerektiğinden bahsettiğini, bütün genç komutanların İstanbul'da toplanmasının doğru olmadığını ifade ettiğini söylemektedir. Ayrıca Karabekir, İsmet Bey’e Doğu Anadolu'da Milli bir Türk Hükümeti kurulması önerisinde bulunduğunu da belirtmektedir. ${ }^{19}$

Bilindiği üzere Mustafa Kemal Paşa 19 Mayıs 1919 yılında Samsun’a ayak basmıştır. ${ }^{20}$ Kurtuluş Savaşı'nın başlangıcını temsil eden bu tarihten sonra Mustafa Kemal Paşa, Kâzım Karabekir Paşa, Ali Fuat Cebesoy, Refet Bele ve Cemal Paşalara telgraf çekerek Amasya'da bir görüşme planladı. Mustafa Kemal Paşa'nın çağrısı üzerine Amasya'da gerçekleşen görüşmeye Ali Fuat Paşa, Rauf Bey ve Refet Bey Bizzat katılırken, Kâzım Karabekir ve Cemal Paşalar ise vicahen katılmışlardır. $^{21}$

Amasya Görüşmesi, Milli Mücadele'nin en önemli eşiklerinden birini teşkil etmektedir. Yapılan bu görüşmede alınan kararların tamamı açıklanmamış, iki gün süren görüşmelerin sonunda bir genelge yayımlanmış ${ }^{22}$ ve genelgede şu kararlar alınmıştır: “...Vatanın bütünlüğü ve milletin bă̆ımsızlı̆̆ tehlikededir. Milletin bă̆ımsızlı̆̆ını, gene milletin kesin kararı ve direnişi kurtaracaktır. Yurtta en güvenli yer olan Sivas'ta Milli bir kongre toplanmalıdır. Her sancaktan, milletin güvenini kazanmış üçer kişi hemen yola çıkarılmalıdır. Durum, her ihtimale karşı milli bir sir olarak tutulmalıdır..."23

Yukarıda alınan kararlardan sonra Kâzım Karabekir Paşa, Sivas’ta toplanacak olan kongreden önce Erzurum' da bir kongre yapılmasını teklif etmiştir. Mustafa Kemal Paşa, Erzurum' da yapılması planlanan kongrenin tüm yurdu temsil etmese de Milli Mücadelenin Doğu Anadolu'da da güçlenmesi adına kritik öneme sahip olacağı düşüncesi ve esas kongrenin yine Sivas’ta gerçekleştirilmesi koşulu ile Kâzım Karabekir Paşa’nın Erzurum'da kongre teklifini kabul etmiştir. ${ }^{24}$

Mustafa Kemal Paşa, Rauf Bey (Orbay) ve maiyetindekiler 3 Temmuz 1919 tarihinde Erzurum'a geldiler. Burada kendilerini Kâzım Karabekir Paşa ve kalabalık bir heyet karşılamıştır. ${ }^{25}$ Gelişen süreç boyunca Mustafa Kemal Paşa ile İstanbul hükümeti arasındaki ilişkiler iyice gerginleşmiş ve İstanbul Hükümeti, 23 Haziran'da Mustafa Kemal Paşa'yı görevden alarak emirlerinin dinlenilmemesini kararlaştırmıştı. ${ }^{26} 7$ Temmuz'u 8 Temmuz'a bağlayan gecede artık ipler kopmuştu ve İstanbul Hükümeti son kez İstanbul'a gelmesi emrini iletmişti. Mustafa Kemal Paşa da emri kabul etmeyince kendisine ordu müfettişliği görevinden azledildiği bildirilmiş, bunun üzerine Mustafa Kemal Paşa, aynı gün askerlikten istifa ettiğini Harbiye Nezaretine bildirip 9 Temmuz günü millete yönelik bir beyanname yayımlamıştır. ${ }^{27}$

19 Kazım Karabekir, Ístiklal Harbimizin Esasları(Yakılan Kitap) (İstanbul: Sinan Matbaası ve Neşriyat Evi, 1972 ), 29.

20 Rauf Bey’de Mustafa Kemal Paşa'nın Samsun'a vardığı haberini aldıktan sonra 8 Haziran 1919 Yılında Bandırma üzerinden Ankara'ya ulaştı. Ardından Ankara'dan Amasya'ya vardı. Hüseyin Rauf Orbay, Siyasi hatıralar (İstanbul: Örgün Yayınevi, 2009), 301.

21 Yaşar Semiz, “Atatürk ve Kâzım Karabekir Paşa”, Selçuk Üniversitesi Türkiyat Araştırmaları Dergisi, sy 4 (01 Aralık 1997): 194.

22 Şerafettin Turan, Türk devrim tarihi, 1. basım (Yenişehir, Ankara : Cağaloğlu, İstanbul: Bilgi Yayınevi ; Bilgi Dağıtım, 2004), 192.

23 Sabahattin Selek, Anadolu ihtilali, c. 2 (İstanbul: Kastaş Yayınları, 1987), 263.

24 Orbay, Siyasi hatıralar, 309.

25 Ergün Aybars, Türkiye Cumhuriyeti Tarihi, c. 1 (İzmir: Zeus kitabevi yayınları, 2004), 154.

26 Kemal H. Karpat, Kısa Türkiye tarihi, 1800-2012, 1. bask1, Timaş yayınları (İstanbul: Timaş, 2012 ), 119.

27 Aybars, Türkiye Cumhuriyeti Tarihi, 1:155-56. 
Kâzım Karabekir Paşa, Mustafa Kemal Paşa'nın istifasından sonra Milli Mücadelenin kaderini değiştiren bir tavır sergileyerek Mustafa Kemal Paşa'nın Milli Mücadele'nin lideri olmasının yolunu açmıştır. Önce sözlü olarak "Hepimiz Emrinizdeyiz Paşam” demiş, ardından da yazılı bir beyanatta bulunarak Mustafa Kemal Paşa’ya olan bağlılı̆̆ını bildirmiştir. Kâzım Karabekir Paşa'nın bu tavrı üzerine Mustafa Kemal Paşa çok duygulanmış ve kendisine sarılarak Karabekir Paşa'yı defalarca öpmüştür. Erzurum Kongresi, Kâzım Karabekir Paşa'nın fikri öncülü ve Doğu Anadolu ile Doğu Karadeniz'deki Milli Direniş örgütlerinin işbirliği sayesinde toplanmıştır. Kongrenin amacı Doğu ve Güney Doğu Anadolu ile Doğu Karadeniz'deki işgallere karşı direnme kararlılığını ortaya koyma ve Ermeni saldırılarına karşı hazırlıklı olmaktı. Kongre, aldığı kararlar bakımından bir bölge kongresi olmaktan ziyade ulusal bir kongre özelliğini taşımıştır. ${ }^{28}$

Kongrenin bitiminden sonra Mustafa Kemal Paşa ve Rauf Bey Sivas'a hareket etmeden önce 28 Ağustos günü Erzurum'da son bir kez daha görüşerek manda fikrinin kabul edilmeyeceğini ve sonuna kadar mücadele edileceğini belirterek, ancak çaresiz kalınması durumunda bağımsızlığa gölge düşmeyecek şekilde Amerikan yardımının kabul edilebileceğini kararlaştırdılar. Karabekir anılarında, bu kararın sadece toplantıda bulunanlar arasında alındığını ve Sivas'ta kesin olarak mücadele kararının alınmasının kararlaştırıldığını belirtmektedir. ${ }^{29}$

4-11 Eylül tarihleri arasında gerçekleştirilen kongrede bütün memleketi ilgilendiren kararlar alınmıştır. Kararların 3. Maddesine göre, ülkenin her hangi bir yerinde gerçekleştirilecek işgallere karşı birlikte hareket edilecektir. 10. Maddede milli teşkilat bir bütün olarak değerlendirilmiş ve Heyet-i Temsiliye'nin idaresi altında olacağı belirtilmiştir. Bu kararlar alınırken Erzurum Kongresi'nde alınan bazı kararların tüzüğünde değişikliklere gidilmiştir. Sivas Kongresi, önemi bakımından Milli Mücadele'nin en önemli safhalarından birini teşkil etmektedir. Alınan kararlar artık ülkenin bütününü kapsamış ve ülkenin kurtuluşu için alınacak tedbirler ve uygulanacak yöntemler masaya yatırılmıştır. ${ }^{30}$

Sivas Kongresi tamamlanmış, kararları hükümete ve ülkenin her tarafına iletilmişti. Damat Ferit Paşa Hükümetinin her türlü engelleme çabalarına rağmen Milli Mücadele yolunda atılması gereken adımlar atılıyordu. Damat Ferit Paşa'nın bütün engelleme çalışmalarına rağmen bu konuda başarısız olması Damat Ferit Paşa ve hükümetini zor durumda bırakmıştı. Gerek Milli Hareketin faaliyetleri gerekse de İstanbul'daki muhalefet Damat Ferit Paşa'yı istifaya zorlamıştı. Sonunda 30 Eylül 1919 tarihinde Hükümet istifa etmek zorunda kalmıştır. Damat Ferit Paşa Hükümetinin istifası aynı zamanda Heyet-i Temsiliye'nin önemli bir başarısıydı. 2 Ekim 1919 tarihinde Ali Rıza Paşa Hükümeti kuruldu. Ali Rıza Paşa Hükümeti, Damat Ferit Paşa Hükümetine nazaran Milli Mücadele'ye daha 1 lımlı bir bakış açısı sergiliyordu. ${ }^{31}$

Amasya'da yapılan görüşmeler neticesinde İstanbul'da Mebusan Meclisinin yeniden açılması kararı alınmıştır. Meclis-i Mebusan, 2 Ocak 1920 tarihinde Padişahın açış nutku ve Sadrazam Ali Rıza Paşa'nın katılımı ile açılmış, ${ }^{32} 28$ Ocak 1920 tarihinde de Erzurum ve Sivas Kongrelerinde alınan kararlar Misak-1 Milli olarak oy birliği ile kabul edilmiştir. ${ }^{33}$ Misak-1 Milli

28 Orbay, Siyasi hattralar, 323-24.

29 Karabekir, İstiklâl Harbimiz, 1:388.

30 Aybars, Türkiye Cumhuriyeti Tarihi, 1:353.

31 Sina Akşin, Ana çizgileriyle Türkiye 'nin yakın tarihi: 1789 - 1980, 6. bask1 (Ankara: İmaj, 1998), 161.

32 Mustafa Balcıŏlu, Direnen Millet-Milli Mücadele, Türkiye Cumhuriyeti Tarihi, c. 1 (Ankara: Atatürk Araştırma Merkezi Yayınlar1, 2011), 185.

33 Zeki Sarıhan, Kurtuluş Savaşı günlüğü: açıklamalı kronoloji, 1ci baskı, Türk Tarih Kurumu yayınları (Ankara: Öğretmen Dünyas1, 1994), 347. 
kararlarının alınması İngiltere'yi harekete geçirmiş ve Osmanlı Devleti'ne baskı yaparak 3 Mart 1920'de Ali Rıza Paşa'yı istifa etmek zorunda bırakmışlardır. ${ }^{34}$ Ardından 16 Mart 1920'de İstanbul'u resmen işgal etmişler ve Meclis-i Mebusan'ın akşamki oturumunu basarak Rauf Bey ve Vasıf Bey'i tutuklamışlardır. ${ }^{35}$

İstanbul'un işgali, kurtuluş mücadelesini yeni bir evreye taşımış, mücadelenin artık Anadolu'dan yönetilmesi kararı alınarak Ankara' da yeni bir meclisin kurulması kararı alınmıştır. Büyük Millet Meclisi, seçim hazırlıklarının tamamlanmasından sonra eski İttihat Terakki Kulübü binasında 23 Nisan 1920 tarihinde Cuma günü görkemli bir dini törenin ardından en yaşlı üye olan Sinop mebusu Şerif Bey'in başkanlığında toplanmıştır. ${ }^{36}$ Birinci gün yapılan ikinci birleşimde mütarekeden o zamana dek geçen süreci anlatıp değerlendiren Mustafa Kemal Paşa, bu konuşmasının ardından yapılan seçimlerde Celalettin Arif Bey’in 109 oyuna karşılık 110 oy alarak başkanlığa seçilmiştir. ${ }^{37}$

Tüm bu gelişmeler yaşanırken bu arada Anadolu topraklarında işgaller devam etmekte, yurdun dört bir yanı yabancı güçler tarafindan ele geçirilmeye çalışmaktadır. Bunlardan Anadolu'nun doğusu da nasibini alacaktır. İtilaf devletlerinin de destekleri ile harekete geçen Ermeniler, Doğu Anadolu'da saldırıya geçmişlerdir. Büyük Millet Meclisi, bu saldırılara son vermek ve Misak-1 Milli'yi uygulama adına harekete geçmeye karar vermiştir. 2 Eylül 1920 tarihinde Kâzım Karabekir komutasındaki birlikler Doğu cephesinde Ermenilere karşı harekete geçerek Sarıkamış, Kars ve Gümrü'yü Ermenilerden almışlardır. Bu harekât neticesinde fazla dayanamayan Ermeni güçleri barış yapmak zorunda kalmış ve 2 Aralık 1920 tarihinde Ermenistan hükümetiyle Gümrü anlaşmas1 imzalanmıştır. Harekâta devam eden Türk birlikleri Artvin ve Ardahan'1 da vatan topraklarına katmışlardır. Bu başarılı harekât neticesinde Ruslarla Moskova ve Kars Antlaşmaları yapılarak Doğu sınırı güvence altına alınmıştır. Bu anlaşmalar mücadele adına Anadolu için umut olmuş, Doğu cephesinden sağlanan destekle Batı Anadolu'da Büyük Millet Meclisinin eli güçlenmiştir. Kâzım Karabekir' in bu başarısı kendisine büyük ün katmıştır. ${ }^{38}$

\section{Görüş Ayrılıkları ve Terakkiperver Cumhuriyet Fırkasının Kuruluşu}

Kurtuluş mücadelesinin askeri safhasının başarıyla sonuçlanmasından sonra sıra siyasi mücadeleye gelmişti. 30 Ağustos’taki zaferden sonra Mudanya Ateşkes Antlaşması yapılmış ve artık barış görüşmeleri Büyük Millet Meclisinin en önemli gündem maddesi olmuştu. Ancak barış görüşmelerinden önce gündemi meşgul eden önemli bir durum İstanbul Hükümeti’nin de

34 Balcığlu, Direnen Millet-Milli Mücadele, Türkiye Cumhuriyeti Tarihi, 1:188.

35 Sarıhan, Kurtuluş Savaşı günlüğ̈̈, 428-30.

36 Kâzım Karabekir Paşa meclisin Cuma günü açılmasını ve yapılan töreni eleştirerek şu ifadeleri kullanmıştır: “... Tarihimizde bu kadar koyu bir taasuplu merasimi diniye ile ilgili hiçbir meclis açılmamıştır. Fetvaları takip eden bu muazzam ihtilafat acaba yer yer başlayan kıyamlara karşı bir sigorta mı olacağı düşünüldü. Ne olursa olsun selabet (İnanç) ile taassubu Meclisi Millinin başlangıcı gününden ayırmak daha ihtiyatlı olurdu. Yani ne Cuma günü intihaba(Seçmeye) ne de bu kadar velveleye lüzum yoktu. Beliğ(Samimi) bir dua lazımı tesiri daha iyi yapardı. Gösterilen bu taassubun idamesi mümkün olamayacağından aksi tesiri daha vahim olabilir. Meclisi Milli 23 Nisan Cuma günü pek dindarane, daha doğrusu pek dervişane bir merasimle açılıyor..." Kâzım Karabekir, İstiklâl Harbimiz, c. 2 (İstanbul: Emre Yayınları, 2003), 617. TBMM Zabıt Ceridesi, 1. Dönem, C. I, 1. Birleşim, s. 1.

3719 Nisan 1920'de Ankara'daki Milletvekilleri ile yapılan görüşmelerde meclisin 22 Nisan Perşembe günü yapılması kararlaştırılmıştı. Ancak halk üzerinde daha tesirli olunacağı düşüncesi ile ertesi gün yani Cuma gününe ertelendi. Balcığlu, Direnen Millet-Milli Mücadele, Türkiye Cumhuriyeti Tarihi, 1:190; Hamdi Gürler, Paşaların gözüyle Milli Mücadele, 1. basım, Tarih dizisi 13 (Kızılay, Ankara: Vadi Yayınları, 2015), 240. TBMM Zabıt Ceridesi, 1. Dönem, C. I, 2. Birleşim, s. 1.

38 Mustafa Tektosun, "Milli Mücadele Döneminde Doğu Cephesi” (Diyarbakır, Dicle Üniversitesi Sosyal Bilimler Enstitüsü Türkiye Cumhuriyeti Tarihi Bilim Dalı, 2007), 42. 
barış görüşmelerinde bulunacağıydı. 27 Ekim 1922 yılında İtilaf devletleri, Ankara ve İstanbul Hükümetlerini Lozan' da toplanacak barış görüşmelerine davet ettiler. ${ }^{39} \mathrm{Bu}$ davetten 10 gün önce de Tevfik Paşa, Mustafa Kemal Paşa'ya haber göndererek müzakereye beraber gideceklerini ve müzakere konularını görüşmek üzere İstanbul'a temsilci göndermesini istedi. Mustafa Kemal Paşa'nın bu teklife cevabı sert oldu ve teklifi reddetti. ${ }^{40} \mathrm{Bu}$ gelişmeler Mustafa Kemal Paşa'ya Saltanatın kaldırılması yönünde bir firsat doğurdu ve Paşa harekete geçti. Kâzım Karabekir ve Rauf Orbay’ın da desteğini alan Mustafa Kemal Paşa, Saltanatı kaldırmıştır. Saltanatın kaldırılmasıyla ilgili olarak Kâzım Karabekir Paşa: "Saltanatın lağvv ve Hilafeti Al Osman'da bırakmak suretiyle tam milli bir çehre ile gitmekliğimizin faydasını, diğer şekillerin içte ve dişta büyük zorluklar doğuracă̆ını izah ettim..."41 dediğini belirtmektedir. Kâzım Karabekir'in bu ifadelerinden de saltanatın kaldırılmasına karşı olmadığını ancak hilafet kurumunun kalması gerektiği düşüncesinde olduğunu görülmektedir.

Saltanatın kaldırılması konusunda her ne kadar derin bir görüş ayrılığı bulunmasa da ilk ve derin görüş ayrılığı cumhuriyetin ilanında olacaktır. Cumhuriyetin ilanı sırasında Trabzon'da bulunan Karabekir Paşa, cumhuriyetin ilanına kuşkulu yaklaşmıştır. Çünkü cumhuriyetin ilanı sürecinde kendisinin görüşlerinin alınmadığ 1 ve Ankara' da olmadığ kırılmıştır. Ayrıca Milli Mücadelenin lider kadrosunda olmasına rağmen ülkenin durumu ile ilgili kendisinin görüşünün alınmaması da kendisini üzmüştür. ${ }^{42}$

Karabekir Paşa, Kurtuluş Savaşının ikinci safhasında katılan kişilerin Atatürk’ün etrafinı doldurması ve bu kişilerin Atatürk ile silah arkadaşlarının arasını açtığını düşünerek şu sözleri sarf etmiştir: "Ankara'ya gitmek zaruretinden bahsederken söylediğim veçhile M. Kemal'i son zaferin mıknatıslı̆̆ şahsiyetin cazibesine kapılarak etrafina üşüşecek döküntülerin şerlerinden korumak ve bazı tehlikeli kaprislerinden uzaklaştırmak mecburiyetinde idim." 43

Mustafa Kemal ve Kâzım Karabekir Paşalar arasındaki bir başka görüş ayrılığı Halifelik kurumunun ilgası neticesinde olmuştur. Bu görüş ayrılığı aynı zamanda bir yol ayrımına da neden olacaktır. Kâzım Karabekir, halifeliğin kaldırılması haberini tıpkı cumhuriyetin ilanında olduğu gibi yine Ankara' da olmadığı bir zamanda Edremit'te öğrenmiştir. Yine cumhuriyetin ilanında olduğu gibi halifeliğinde kaldırılış şeklini eleştirmiş ve kanunun Ankara'da birkaç kişi arasında kararlaştırılmasından yakınmıştır. Kararın yeterince tartışılmadığını, karara karşı oluşabilecek tepkilerin yeterince düşünülmediği ve bu konuda acele edildiğini iddia etmiştir. ${ }^{44}$

Atatürk ile silah arkadaşları arasındaki fikri bölünme artık fiili bölünmeye doğru geri dönülemeyecek bir şekilde ilerliyordu. Fethi Okyar'ın “İlk Beşler” dediği Mustafa Kemal, Kâzım Karabekir, Ali Fuat Cebesoy, Rauf Orbay ve Refet Bele gibi Kurtuluş Savaşının fikri ve fiili temelini atan liderlerin ülkenin kurtuluşu için gösterdikleri birliktelik inkılap hareketleri neticesinde iyice açılmış Terakkiperver Cumhuriyet Fırkasının (TCF) kuruluşu ile ipler artık kopmuştu. ${ }^{45}$

9 Eylül 1924’te Kâzım Karabekir, Rauf Bey, Refet Bey ve Ali Fuat Cebesoy, İzmir'de Rauf Bey'in annesinin evinde bir araya geldiler. Buradaki toplantıda Ülkede hafiyecilik ve jurnalciliğin başladığını, milletvekillerinin bile rahatça düşüncelerini açıklayamadıklarını, eleştiri yapmanın

40 Atatürk, Nutuk, 1:914; Aybars, Türkiye Cumhuriyeti Tarihi, 1:353-54.

41 Kâzım Karabekir, Paşaların kavgası: inkilap hareketlerimiz (İstanbul: Emre Yayınları, 2000), 91.

42 Aybars, Türkiye Cumhuriyeti Tarihi, 1:353.

43 Karabekir, Paşaların kavgası, 87.

44 Karabekir, 252.

45 Fethi Okyar, Üç Devirde Bir Adam (İstanbul: Tercüman, 1988), 339. 
bile serbest olmadığını, kendilerine karşı bir husumet olduğunu belirterek bunların önüne geçmek için mecliste toplanmayı düşünmüşler ve bu kararları almak için Meclisin açılmasını beklemeyi kararlaştırmışlardır. ${ }^{46}$ Ardından Ekim ayında yeniden toplanan Kâzım Karabekir, Rauf Bey, Refet Bey ve Ali Fuat Cebesoy gibi mücadelenin önemli isimleri yeni bir partinin kuruluşu için harekete geçmişler ve 26 Ekim'de Kâzım Karabekir, ${ }^{47} 30$ Ekim'de de Ali Fuat Cebesoy ordudan istifa etmişlerdir. ${ }^{48} \mathrm{Bu}$ aynı zamanda yeni bir partinin kurulması yönünde atılan ilk adımlardı.

Yeni bir patinin kuruluşu ile ilgili tartışmaların devam ettiği günlerde Mecliste Mübadele ve İskân Bakanlığı hakkında gensoru görüşülüyordu. Gensoru hakkında yapılan tartışmalar sertleşmişti. Aynı gün yapılan gensoru önergesinde İsmet Paşa hükûmeti 19 ret oyuna karşıllık 148 kabul oyu ile güvenoyu aldı. ${ }^{49}$ Gensoru oylaması, Kâzım Karabekir, Rauf Bey, Refet Bey ve Ali Fuat Paşa için Halk Fırkası'ndan ayrılmanın vakti geldiğini göstermişti. Nitekim öyle de oldu ve ertesi gün gensoru önergesine ret oyu veren 11 milletvekili Halk Fırkasından istifa etmişlerdir. 10 Kasım'daki istifaların ardından yeni istifalar da birbirini takip etmiş, 13 Kasım'da da Ali Fuat Cebesoy başta olmak üzere 13 milletvekili daha istifa etmiştir. ${ }^{50}$ Milletvekillerin istifasından sonra artık yeni bir parti kurulacağı kesinleşmişti. İstifa eden milletvekilleri Erzincan milletvekili Sabit Bey'in evinde toplanmışlardır. ${ }^{51}$ Yapılan toplantıda kurulacak partinin programı ve nizamnamesi hazırlanmış ve 17 Kasım 1924 yılında partinin kuruluş dilekçesi dâhiliye vekili Recep Peker'e verilmiştir. ${ }^{52}$

\section{Kâzım Karabekir'in Terakkiperver Cumhuriyet Furkasındaki Faaliyetleri}

Kâzım Karabekir Paşa 8 ve 13 Kasım'daki istifaların ardından 25 Kasım 1924'te Halk Fırkasından istifa etmiştir. ${ }^{53}$ İstifasını geç vermesinin nedeni ordu müfettişi olarak görevinden istifa etmesinden sonra devir teslim işlemlerinin uzamasıdır. Karabekir, 25 Kasım'daki istifasından sonra 27 Kasım'da oy birliği ile Terakkiperver Cumhuriyet Fırkası'nın başına getirilmişstir. ${ }^{54}$

Kâzım Karabekir Paşa, parti lideri olmasına rağmen parti teşkilatında fazlaca etkin olmamıştır. Parti teşkilatı ile firka sekreteri Ali Fuat Paşa'nın ilgilendiğini belirtmekte ve kendisinin daha ziyade gurup müzakerelerini idare etmekte olduğundan bahsetmektedir. TCF'deki faaliyetleri daha çok meclis oturumlarını düzenlemek, parti hakkında basına bilgi vermek ve meclis oturumlarında parti adına görüşlerini belirtmek olmuştur. ${ }^{55}$

Kâzım Karabekir, TCF Genel Başkanı olarak yerli ve yabancı basında partisinin görüşlerini ortaya koyan çeşitli açıklamalarda bulunmuştur. Fransız Le Temps gazetesi özel muhabiri Poljantizon'a partisinin görüşleri hakkında bilgi verdiği görüşmede Karabekir, Türk dış siyasetinin Doğu veya Batılı bir siyaset olmasından ziyade içinde bulunulan coğrafyadan dolayı milli bir

46 Ali Fuat Cebesoy, Siyasi Hatıralar Büyük Zaferden Lozan'a Lozan'dan Cumhuriyete (İstanbul: Temel Yayınları, 2011), 49699.

47 Karabekir, Paşaların kavgası, 315.

48 Ayfer Özçelik, Ali Fuat Cebesoy: 1882-10 Ocak 1968 (Ankara: Akçağ, 1993), 297.

49 TBMM Zabut Ceridesi, 2. Dönem, C. II, 2. Birleşim, ss. 167-168.

50 Tanin,15 Kasım 1924; Ali Kılıç, Atatürk'ün sırdaşı: Kılıç Ali’nin anıları, 1. basım, Türkiye İş Bankası Kültür yayınları 409 (İstanbul: Türkiye İş Bankası, 2005), 231.

51 Orbay, Siyasi hatıralar, 595-96.

52 Kılıç, Atatürk'ün sırdaşı, 99; Orbay, Siyasi hatıralar, 595.

53 Vakit, 26 Kasım 1924; Vatan, 26 Kasım 1924; Kılıç, Atatürk'ün sırdaşı, 23.

54 Özçelik, Ali Fuat Cebesoy, 310.

55 Sümer Kılıç, İstiklal Mahkemeleri Adil miydi(İzmir Suikasti İddianame ve Kazım Karabekir'in Savunması) (İstanbul: Emre, 1994), 124-25. 
dış siyaset olması gerektiğini ve herhangi bir ülkeye kin veya nefret gütmediklerini, bu konuda Cumhuriyet Halk Fırkası ile aynı görüşte olduklarını belirtmiştir. İstiklal Gazetesine verdiği demeçte de Teşkilat-1 Esasiye Kanunu'nun milletten yetki alınmadıkça değiştirilmemesi gerektiğini savunmuştur. ${ }^{56}$

Kâzım Karabekir, muhalefet partisi lideri olarak birçok kez meclis oturumunda söz alarak konuşmalarda bulunmuştur. Nitekim Kâzım Karabekir'in parti lideri olarak en etkin faaliyette bulunduğu alanlardan bir tanesi meclis oturumlarında sık sık söz alarak konuşmasıdır. Bu hususta, Feridun Fikri Beyden sonra partisi adına en çok söz alan ikinci milletvekili olmuştur. Mecliste yaptığg konuşmaları göz önünde bulundurduğumuzda Ekonomi, Siyaset, Eğitim ve Askerlik gibi birçok konuda fikirlerini mecliste dile getirmiştir. ${ }^{57}$

Kâzım Karabekir, 26 Ocak 1925 tarihinde TBMM'de görüşülmekte olan Askeri Şura kurulması ile ilgili yasa tasarısı hakkındaki görüşlerini mecliste yaptığı uzun bir konuşma ile açıklamıştır. Bu konuşmasında Birinci Dünya Savaşında Almanya, Avusturya-Macaristan İmparatorluğu ile Osmanlı Devletinin Balkan Savaşlarından sonraki askeri yapısı ile İngiltere, Fransa ve İtalya'nın askeri yapısını karşılaştırmış, Almanya, Avusturya-Macaristan İmparatorluğu ve Osmanlı Devleti'nde savaşı bir veya birkaç kişi yönetirken; İngiltere, İtalya ve Fransa'nın Ordu Şurası ve Müdafaa Komitesi kurarak savaşı daha iyi idare ettiklerinden bahsetmiştir. ${ }^{58}$ Karabekir, konuşmasının devamında Birinci Dünya Savaşından sonra Avrupa'da ordu yönetiminde değişikliklerin olduğunu, artık orduyu bir veya birkaç kişinin yönetmediğini, bunun yerine askeri konularda uzmanlaşmış kişilerden oluşan heyetlerin ordu yönetiminde söz sahibi olduğundan bahsetmektedir. Bu konuda da ordu yönetiminde uzmanlaşmış kişilerden oluşan bir şuranın oluşturulması gerektiğini ifade etmiştir. Bu düşüncesi daha önce belirttiğimiz ikili meclis sistemi olan Uzmanlar Meclisini aklımıza getirmektedir. Bu düşüncelerine bakıldığında kendi önceden beri aklında bulunan uzmanlığın önemini bir kez daha öne çıkarmıştır. Ayrıca ordu yönetimindeki düşüncesi, ordu politikasının hükümetlerin politikalarına göre değişmemesi gerektiği yönündedir. ${ }^{59}$ Kâzım Karabekir, tartışılan Askeri Şura tasarısı ile ilgili Cumhurbaşkanının Askeri Şuraya başkanlık etmesini doğru bulmamaktadır.

Kâzım Karabekir, askeri konularla ilgili mecliste uzun konuşmalar yapmıştır. Mecliste askeri konularda bu kadar uzun konuşmalar yapmasında kendisinin asker kökenli olması etkili olmuştur. Askerlik mesleğinden gelmenin sağladığı avantajla konulara ve sorunlara vakıf olma rahatlığını yaşamış, bu minvalde mecliste askeri konular hakkındaki düşüncelerini daha kolay ifade etmişstir. 19 Mart 1925 tarihli meclis oturumunda Milli Savunma Bakanlığı bütçesi görüşülürken yine bu konu da uzun bir konuşma yapmış, askerlerin terfileri, askeri fabrikaların kurulması ve işletilmesi, sivil halkın savunma konularında bilgilendirilmesi ve bilinçlendirilmesi, askeri okullar ve ordunun insan kaynağının karşılanması gibi konular da görüşlerini uzun uzadıya anlatmıştır. ${ }^{60}$

TCF lideri Kâzım Karabekir'in mecliste askeri konulardan sonra üzerinde en çok durduğu ve düşüncelerini ifade ettiği bir husus ta eğitim konusu olmuştur. 25 Şubat 1925tarihinde Muvazene-i Umumiye Kanun Layihası (Genel Bütçe Yasa Tasarıs1) görüşülürken Maarif Vekâleti (Milli Eğitim Bakanlığı) bütçesi hakkında uzun bir konuşma yapmıştır. ${ }^{61}$ Daha sonraki yıllarda Çocuk Davamız

\footnotetext{
56 Çiftçi, “Kâzım Karabekir'in Siyasal Hayatı”, 235-36.

57 Çiftçi, 240.

58 TBMM Zabıt Ceridesi,2. Dönem, C. XII, 41. Birleşim, s. 339.

59 TBMM Zabit Ceridesi, 2. Dönem C. XII, 41. Birleşim, s. 341.

60 TBMM Zabıt Ceridesi, 2. Dönem, C. XII, 41. Birleşim, ss. 59-65

61 TBMM Zabıt Ceridesi, 2. Dönem, C. XIV, 1. Birleşim, s. 292.
} 
adlı eserine koyduğu bu konuşmasında Türk eğiti sistemini Tanzimat, Meşrutiyet ve Cumhuriyet olmak üzere üç döneme ayırmıştır. Tanzimat’tan bugüne kadarki eğitim sistemi hakkında bilgi vermiştir. Bu konuşmasında eğitimin milli olmasının gerekliliği üzerinde durmuş ve bu yolla ortak bir bilinç olması gerektiğini ifade etmiştir. Karabekir'e göre ülkemizde bilimsel gelişmelerin ve buluşların görülmemesinin nedeni hür bir idare anlayışının olmamasıdır. Batılı toplumların bizden ileri olmasının nedenleri arasında eğitim sistemlerinde milliyetçi ve özgürlükçü bir anlayışa sahip olmaları yatmaktadır. Ona göre Eğitimde kuramsal bilgilere verilen ağırlığın yerini Birinci Dünya Savaşından sonra uygulamaya ve ekonomik verimliliğe yönelik yaklaşımlar almıştır. ${ }^{62}$

25 Şubat'taki konuşmasında beden eğitimi konusuna da değinmiştir. Karabekir'e göre bir milletin güçlü olabilmesi için gençlerini hem ulusal savunma hem de beden eğitimi yönünde iyi yetiştirilmesi gerekmektedir. Konuşmasının devamında iktisadi düşüncenin öneminden bahsetmiş, ekonomide Almanya'yı örnek göstererek milliyetçilik yapılması gerektiğini savunmuş ve Türkiye'de yerli ürünlerin kullanımı teşvik edilmesi gerektiğini ifade etmiştir. Konuşmasında ayrıca kadınlara da değinmiş ve kadınlarında kendilerine uygun iş alanlarında çalışma yaşamına katılmasını önermiştir. ${ }^{63}$

Kâzım Karabekir ve arkadaşlarının meclis dışında en yoğun olarak ilgilendiği konu parti teşkilatlanması olmuştur. Partinin ülke içindeki teşkilatlanması çok ta zor olmamıştır. Gerek inkılaplara karşı olanlar, gerek eski ittihatçılar ve gerekse de CHF'ye küskün olanlar partiyi bir firsat olarak değerlendirmiş ve özellikle İstanbul basını ve muhalif kişilerin desteği ile partiye olan ilgi yoğun olmuştur. TCF ilk şubesini 27 Kasım 1924 tarihinde Urfa'da açmış, ${ }^{64}$ daha sonra Sivas, Trabzon, İstanbul, Eskişehir, Siverek, Erzurum, Ordu, İzmir, Afyonkarahisar (Karahisarısahip) Amasya, Samsun, Sinop, Maraş, şubelerini de açmıştır. ${ }^{65}$

TCF, ilk ve tek Vilayet Kongresini15 Mayıs 1925'te İstanbul'da gerçekleştirmiştir. ${ }^{66}$ $\mathrm{Bu}$ kongre, muhalif fırka olarak TCF'nin siyasi hayatına son verilmeden önce yapabildiği son faaliyetlerden biridir. Çünkü kongreden yaklaşık iki hafta sonra, önce Şark İstiklal Mahkemesi, TCF'nin bu bölgedeki Şubelerini kapattırmış, buna bağlı olarak Takrir-i Sükûn Kanunu hükümlerine göre 3 Haziran 1925'te hükümet kararıyla TCF, resmen kapatılmıştır. Oysaki kongrenin açış konuşmasını yapan Vasıf Bey Şarktaki bölücü ve irticai isyana karşı hükûmetin başarısından duyduğu sevinci dile getirmişti. ${ }^{67}$

TCF, parti teşkilatlanmasını sürdürdüğü sırada, daha kuruluşundan bir ay geçmeden bir seçimle karşı karşıya kalmıştı. 1924 yılının aralık ayında çeşitli nedenlerle mecliste boşalan 13 milletvekilliği için ara seçimler yapılmış, ancak TCF kurulduktan bir ay sonra karşı karşıya kaldığ 1 bu seçimlere teşkilatlanmasını henüz gerçekleştiremediği için katılamamıştır. ${ }^{68}$

62 TBMM Zabıt Ceridesi, 2. Dönem, C. XIV, 1. Birleşim, s. 293.

63 TBMM Zabıt Ceridesi, 2. Dönem, C. XIV, 1. Birleşim, s. 301.

64 Erik Jan Zürcher, Cumhuriyet'in ilk yıllarında siyasal muhalefet Terakkiperver Cumhuriyet Furkasi (1924-1925) = Political opposition in the early Turkish Republic: the Progressive Republican Party, 1924-1925 (İstanbul: İletişim, 2003$), 95$.

65 Cebesoy, Siyasi Hatıralar Büyük Zaferden Lozan'a Lozan'dan Cumhuriyete, 540-42.

66 Zürcher, Cumhuriyet'in ilk ylllarında siyasal muhalefet Terakkiperver Cumhuriyet Firkası (1924-1925) = Political opposition in the early Turkish Republic, 129.

67 Özgür Güvercin, “Terakkiperver Cumhuriyet Fırkasının Türk Siyasal Hayatındaki Yeri” (Yüksek Lisans, Bolu, Abant İzzet Baysal Üniversitesi, Sosyal Bilimler Enstitüsü Tarih Ana Bilim Dalı, 2007), 47.

68 İstanbul'daki şubesini de ancak 28 Ocak 1925 yılında açabildi; Zürcher, Cumhuriyet'in ilk yıllarında siyasal muhalefet Terakkiperver Cumhuriyet Firkası (1924-1925) = Political opposition in the early Turkish Republic, 94. 


\section{Terakkiperver Cumhuriyet Fırkasının Kapatılması ve Kâzım Karabekir'in Yargılanması}

1925 yılının Şubat ayında, Anadolu'nun doğusunda başlayan Şeyh Sait ayaklanması, ülke gündemine oturmuş ve önemli sonuçlara gebe olmuştu. Şeyh Sait İsyanı, Lozan Barış Anlaşması'nda çözüme kavuşturulamayan Musul Sorununun İngiltere ile bir çözüme ulaştırılmaya çalışıldığı bir döneme denk gelmişti. Lozan Barış Anlaşmasının Irak sınırı ile ilgili olan maddesine göre taraflar arasında dokuz ay içerisinde bir anlaşma sağlanamaması durumunda mesele Milletler Cemiyeti'ne devredilecekti. ${ }^{69}$

İsyanın ilk patlak verdiği dönemlerde hükümet ile muhalefet arasındaki gerginliğin dozu artıyordu. İsmet Paşa Hükümeti, Doğuda sıkıyönetimin ilan edildiği bölgelerde çalışan İstiklâl Mahkemeleri tarafindan verilecek idam cezalarını meclis tarafindan onaylanmaksızın yerine getirilmelerini sağlayacak bir yorum kararı istiyordu. Bu durum muhalefet ve hükümet arasındaki gerginliği arttırmıştı. ${ }^{70}$ Kâzım Karabekir Paşa, çıkarılacak bu kanun tasarısının çok ağır hükümleri bulunduğunu ve hükümetin bunu gerekçe göstererek muhalefeti susturup, düşünce özgürlügünün kalmayacağını savunmuştur. ${ }^{71}$ Takrir-i Sükûn Kanunun konuşulduğu oturumda İsmet Paşa hükümeti bu kanunla birlikte sert önlemler almaya başlamış ve TCF'ye de cephe almıştır. Açıkça kanıtlanmamış olmakla beraber İstiklâl Mahkemesi, TCF'yi isyanla ilişkili bulmuştu. ${ }^{72}$ Mahkeme "Terakkiperver Fırka'nın buradaki şubelerini ayaklanmaya destek oldukları gerekçesiyle 25 Mayıs 1925 tarihinde bu bölgedeki partinin bütün şubelerini, kapatma kararını almıştır. ${ }^{73}$

Şeyh Sait isyanının getirdiği gerilimli sürecin sonunda partinin programında bulunan "dini inançlara saygılı olma" hükmü 1924-1925 yılları Türkiye’si için tansiyonu son derece yüksek bir ortam yaratacak, özellikle Atatürk'ün gerçekleştirmeyi hedeflediği çağdaşlaşma hareketlerini önleyebileceknitelikteydi. Buyüzden TerakkiperverCumhuriyetFırkası13 Haziran'dakapatılmıştır. ${ }^{74}$

Parti’nin kapatılmasına ilişkin Bakanlar Kurulu kararında parti tüzüğünün altıncı maddesindeki hükmü ile dinin siyasete alet edildiği, bunun da gerici çevreleri cesaretlendirdiği ve rejimi tehdit ettiği saptaması yapılıyor ve buna izin verilemeyeceği vurgulanıyordu. Bu madde ile de partinin kapatılma gerekçesi oluşturuluyordu. Bu ilk parti kapatma olayıyla birlikte Cumhuriyet döneminde dinin siyasete alet edilmesi, parti kapatılmasının temel gerekçesi haline gelecek ve cumhuriyet tarihinde de birçok parti dinin siyasete alet edildiği gerekçesi ile kapatılacaktır.

İsmet İnönü Partinin kapatılması ile ilgili düşüncelerinde Şeyh Sait İsyanı ile TCF arasında doğrudan bir ilişki bulunmadığını ifade etmektedir. İnönü’ye göre yeni siyasal rejime karşı olanlar, TCF'den ve onun din ile ilgili maddesinden güç almışlardır. Başka bir ifadesinde de İnönü, o günkü koşullarda rejimi yerleştirebilmek için TCF'yi kapatmayı gerekli gördüklerini belirtmiştir. İnönü, Cumhuriyet döneminde TCF'yi kapatmayı bir hata olduğunu belirterek eğer rejimi koruma korkusu ile TCF kapatılmasaydı demokratik geleneğin şimdiye kadar yerleşmiş olacağını ifade etmiştir. ${ }^{75}$ Eski Başvekil Fethi Bey, TCF'nin kapatılmasını değerlendirirken TCF'nin kapatılmasından

69 İsmail Soysal, Tarihçeleri ve açıklamaları ile birlikte: Türkiye'nin siyasal andlaşmaları (Ankara: Türk Tarih Kurumu Yayınları, 2000), 85.

70 Mahmut Goloğlu, Türkiye Cumhuriyeti tarihi (İstanbul: Türkiye İş Bankası Kültür Yayınları, 2011), 224.

71 Mehmet Özalper, "Bir Muhalefet Partisinin İlgası: Terakkiperver Cumhuriyet Fırkası”, Anemon Muş Alparslan Üniversitesi Sosyal Bilimler Dergisi 2, sy 1 (16 Mart 2015): 128.

72 Kemal H Karpat, Türk demokrasi tarihi [sosyal, kültürel, ekonomik temeller (Timaş: İstanbul, 2012), 134.

73 Özalper, "Bir Muhalefet Partisinin İlgası", 128.

74 Özalper, 129.

75 Çiftçi, “Kâzım Karabekir'in Siyasal Hayatı”, 265-66. 
sonra ülkede tek partili yaşamın hâkim olduğunu ve siyasal yaşamın, önceden belirlenen kişilerin seçilmesinden ibaret olduğunu ifade etmiştir. ${ }^{76}$

Kâzım Karabekir, TCF'nin kapatılması ile ilgili görüşlerinde TCF'nin kapatılmasının nedenini parti programındaki 6. maddenin bulunması olarak görmemiş, programdaki altıncı maddenin sakıncalı görülmüş olması durumunda kendilerinden istenildiği takdirde bu maddeyi kaldırabileceklerini ifade etmiştir. Karabekir'e göre TCF'nin kapatılmasının altında yatan neden hükümetin muhalif bir parti istememesidir. Bu iddiasına dayanak olarak da 1930 yılında kurulan SCF'nin parti programında böyle bir madde bulunmamasına rağmen yine de kapatılmasını göstermektedir. ${ }^{77}$ Ayrıca, İstanbul'da düzenlemeyi planladıkları kongrede programdaki altıncı maddeyi kaldırmayı vaat ettiklerini ancak kongreden bir gün önce yapılan baskın nedeni ile bunu yapamadıklarını ifade etmiştir. ${ }^{78}$ Karabekir, Kürt Meselesi adlı eserinde TCF'nin kapatılmasını eleştirirken lideri olduğu partinin kapatılmasının asıl gerekçesinin Şeyh Sait isyanı olmadığı, asıl nedeninin TCF'nin çoğunluğu alma korkusu olduğunu ileri sürmüştür. ${ }^{79}$

TCF kapatıldıktan sonra Kâzım Karabekir'in milletvekilliği sıfatı düşmemiş, TBMM'de bağımsız milletvekili olarak devam etmiştir. Partinin kapatılmasından sonra Karabekir ve arkadaşları TBMM'de bir süre daha dayanışmayı sürdürdükleri ve bir grup olarak hareket ettikleri görülmektedir. Bu durum hem TBMM'deki oylamalarda hem de gündemdeki bazı konuları grup halinde müzakere ettikleri olmuştur. Gerek Karabekir, gerekse de Ali Fuat Cebesoy, anılarında bu konudan bahsetmektedirler. Örneğin, TCF kapatıldıktan sonra Karabekir ve arkadaşları Musul Sorunu, Medeni Kanunu'nun kabulü konularında aralarında toplantı yaparak bu konuları müzakere etmişlerdir.

TCF'nin ve muhalif gazetelerin kapatılması Türkiye'de tek partili siyasal yönetimin fiili olarak başlatmıştı. TBMM ikinci devresini yaşıyor ve eski TCF'li liderlerin milletvekilliği devam ediyordu. Eski TCF'liler mecliste bulunmakla beraber Takrir-i Sükûn Yasası'nın devamı ve İstiklal Mahkemeleri'nin işleyiş tarzı ülkede muhalefeti yok ettiği için ülkede gerçekçi olmayan bir sükûnet ortamı vardı. Böyle bir ortamda Atatürk, toplumsal ve hukuksal yaşama ilişkin devrim atılımlarını rahatlıkla yürütebiliyordu. Ancak bu devrimlere karşı alttan alta tepkiler yükseliyordu. İşte bu ortamda 1926 yılına gelindiğinde Türk siyasal yaşamında izlerinin etkisi uzun süre yaşanacak bir olay gerçekleşmiştir. İzmir' de Atatürk’e karşı bir suikast girişimi gerçekleşmiş, bu suikast girişiminin ucu Kâzım Karabekir'e kadar uzanmış ve Paşa, tutuklanmıştır. ${ }^{80}$

Kâzım Karabekir'in Atatürk'e yönelik suikast girişimi nedeniyle tutuklanması haberi ülkede büyük bir şaşkınlığa yol açmıştır. Başvekil İsmet Paşa, Karabekir'in tutuklanmasını doğru olmadığını düşünerek onu serbest bıraktırmıştır. Uğur Mumcu'nun Gazi Paşa'ya Suikast adlı eserinde Dâhiliye Vekili Recep Peker Bey, İsmet Paşa'nın bu tutumundan dolayı kendisini 18 Haziran'da İzmir'de bulunan Mustafa Kemal Paşa'ya şikâyet etmiştir. ${ }^{81}$ Bunun üzerine Atatürk, İsmet Paşa'yla birçok defalar görüşerek meselenin ciddiyetini anlatmış ve TCF liderlerinin işin içinde olduğunu kendisine söylemiştir. İsmet Paşa'nın paşaların tutuklanmasından duyduğu endişenin kaynağı bu paşaların Kurtuluş Savaşı'nda önemli rol oynamaları ve bu durumun insanlarda acı ve direnme duygusu doğuracağı endişesidir. Karabekir, 20 Haziran'da kendisini

76 Okyar, $\ddot{U} c ̧$ Devirde Bir Adam, 531.

77 Kâzım Karabekir, Nutuk ve Karabekir'den cevaplar, c. 6 (Sultanahmet, İstanbul: Emre Yayınları, 1997), 1721.

78 Kâzım Karabekir, Nutuk ve Karabekir'den cevaplar, c. 7 (Sultanahmet, İstanbul: Emre Yayınları, 1997), 2077.

79 Kâzım Karabekir, Kürt meselesi, Emre Yayınları Yakın Tarih serisi, 3220 (Cağaloğlu, İstanbul: Emre Yayınları, 1994), $37-38$.

80 Ali Ulvi Özdemir, “Kazım Karabekir’in Muhalefete Geçişi ve Bu Süreçte Devlet Tarafından İzlenmesi”, t.y., 148.

81 Uğur Mumcu, Gazi Paşa ’ya Suikast (İstanbul: Um:ag, 2010), 40. 
tutuklayanlara Başvekil İsmet Paşa'yı görmek istediğini söylemiş, tutuklanma olayını duyan İsmet Paşa çok eski arkadaşı olan Karabekir'in böyle bir işin içinde bulunacağını ihtimal vermeyerek suikast olayının düzmece olduğunu düşünmüştür. ${ }^{82}$ İsmet Paşa, Ankara Emniyet Müdürüne emir vererek Karabekir'in serbest bırakılmasını sağlamıştır. İsmet Paşa'nın bu davranışı üzerine Ankara İstiklal Mahkemesi derhal Atatürk'ü devreye koyarak bu duruma itiraz etmiş ve gerekirse İsmet Paşa'nın da tutuklanabileceğini İsmet Paşa'ya hissettirmiştir. Kılıç Ali, anılarından başvekil İsmet Paşa'nın da tutuklanmak istendiğini belirtmiştiir. ${ }^{83}$ Devreye giren Atatürk, suikast planının doğru olduğunu görmesi için İnönü'yü İzmir'e çağırmış ve burada İnönü'yü ikna etmiştir. İnönü'nün ikna olması üzerine Karabekir 22 Haziran'da tekrar tutuklanmıştır. ${ }^{84}$

Ankara İstiklal Mahkemesi, İzmir'de Elhamra sinemasında (Bugünkü Milli Kütüphane) 26 Haziran günü duruşmalara başlamıştır. Ankara İstiklal Mahkemesi Savcılığı, Karabekir, Ali Fuat ve Refet Paşaları suikast ilanından haberleri olmalarına rağmen durumu hükümete bildirmemekle suçlamıştır. Paşaların sözlü duruşması 3 Temmuz'da başlamış, Karabekir ise 4 Temmuzda ifade vermiş̧tir. ${ }^{85}$ Söz konusu duruşmada Kâzım Karabekir'in daha çok TCF'ye neden geçtiği ile ilgili sorular sorulmuştur. Bu sorulara cevap olarak Karabekir, mütarekeden sonra Gazi Paşa'yı başlarına geçirdiklerinde ülkenin tek dayandığı askeri kuvvetin kendisi olduğu, her devrimden sonra görüldüğü gibi amaca ulaştıktan sonra ortaya çıkan asalakların birliği bozduğu ifade etmiştir. Bu kişilerin kendisi ve arkadaşlarını sürekli Atatürk'e karşı karalamaya çalıştıklarını Halk Fırkası'ndan ayrıldıktan sonra İsmet Paşa ile görüştüğünü evine çekilmeyi muhalif fırka kurma işiyle falan ilgilenmemeyi düşündüğüm halde bu kişilerin kışkırtmaları karşısında buna mecbur kaldığını belirtmiştir. ${ }^{86}$ Mahkeme başkanı Ali Çetinkaya’nın Faik Bey’in kendisinin(Karabekir) de haberdar olduğunu düşündüğünü belirtmesi üzerine Karabekir, eğer suikast girişiminden haberi olan arkadaşları olmuşsa bunların partiyi fesih etme ihtimalinden çekindikleri için kendisine bildirmemiş olabileceklerini ifade etmiştir. ${ }^{87}$

13 Temmuz 1926'da mahkeme Elhamra sinemasında kararı açıklanmıştır. Açıklanan kararda Kâzım Karabekir ve diğer paşaların beraatine karar verilirken suikast tertipçisi olarak aralarında İsmail Canbulat Bey'in da olduğu on beş kişinin idamına karar vermiştir. Açıklanan kararda eski İT üyelerinin davası ise mevcut davadan ayrılarak Ankara'da görülmelerine karar verilmiştir. ${ }^{88}$

Kurtuluş Savaşındaki başarı ve katkıları yadsınamayacak olan Kâzım Karabekir'in 5 Aralık 1927 tarihinde askerlikle de ilişiği kesilecektir. 1924 yllında Ordu Müfettişliğinden istifa etmiş, ancak askerlik sıfatı devam ediyordu. 29 Kasım 1927 tarihinde Milli Savunma Bakanı Mustafa Abdülhalık Bey'in başlattığı bir yazışma sonucunda kendi görüşü sorulmadan askerlikle ilişiği kesilmiş ve Korgeneral olarak emekliye sevk edilmiştir. ${ }^{89}$

25 Nisan 1931 tarihindeki erken seçimlerde meclise girebilmek İstanbul'dan bağımsız aday olmuş ancak seçilememiştir. Karabekir aday seçilememesi ile ilgili olarak milletvekili olmasının

82 Falih Rıfkı Atay, Çankaya: Atatürk'ün doğumundan ölümünekadar, Pozitif Yayınları Sosyal Tarih Dizisi (İstanbul: Pozitif Yayınlar1, 2004), 440.

83 Kılıç, Atatürk'ün sırdaşı, 425.

84 Mumcu, Gazi Paşa'ya Suikast, 22.

85 Ergün Aybars, İstiklal Mahkemeleri, c. 1 (İzmir: İleri, 1995), 438-44.

86 Kılıç, İstiklal Mahkemeleri Adil miydi(İzmir Suikasti İddianame ve Kazım Karabekir'in Savunması), 53.

87 Çiftçi, "Kâzım Karabekir'in Siyasal Hayatı", 282.

88 Aybars, Istiklal Mahkemeleri, 1:438.

89 BCA, 030.11.1/36.33.7; Çiftçi, "Kâzım Karabekir’in Siyasal Hayatı”, 302. 
engellendiğini ileri sürmüştür. ${ }^{90}$

Kâzım Karabekir'in 1933 yılı içerisinde yaşadığı önemli olaylardan biri de kendisine suikast girişimi hazırlı̆̆ının olduğudur. Karabekir, kendisine yönelik bir suikast girişiminin olduğunu ve bunun İstanbul Valiliğinde müzakere edildiğini iddia etmiştir. ${ }^{11} 9$ Ağustos 1933 tarihinde İsmet Paşa'ya gönderdiği mektupta kendisine karşı suikast hazırlığı olduğunu söylemekte ve karşı tehditte bulunmaktadır. ${ }^{92}$

Hararetli geçen 1933 yılının ardından 1934 ve 1936 yıllarında Atatürk ile Kâzım Karabekir’i barıştırma girişimleri olmuş ancak olumsuz sonuçlanmıştır. Ali Fuat Cebesoy’un aracılığı ile 1934 yılındaki 2. Türk Dil Kurultayında Atatürk ile barıştırılmaya çalışılsa da bu gerçekleşmemiştir. Atatürk ile barıştırılma çabalarının da olumsuz sonuçlanması üzerine Kâzım Karabekir, Atatürk’ün ölümüne kadar bir nevi inzivaya çekilmiş ve anılarını yazmakla meşgul olmuştur. ${ }^{93}$

Kâzım Karabekir'in yeniden siyaset sahnesine dönüşü Atatürk'ün vefatı ile olmuştur. Cumhurbaşkanı seçilen İsmet İnönü, rejim ile ters düşen eski asker ve siyasetçileri kazanma yoluna gitmiş ve 1938 yılının sonunda Celal Bayar aracılığı ile Karabekir'e milletvekili olma önerisinde bulunmuştur. 31 Aralık 1938 tarihinde de İstanbul'da milletvekili seçilmiştir. 1938 yılından itibaren yeniden siyaset sahnesine dönen Karabekir, 5 Ağustos 1946 tarihinden 26 Ocak 1948 tarihinde ölümüne kadar bu görevini sürdürmüş̧ür. ${ }^{94}$

\section{Sonuç}

Kâzım Karabekir, 19. yüzyılın sonları ile 20. yüzyılın ilk yarısında Türk siyasal yaşamında birçok olayın içinde aktif olarak bulunmuştur. Asker kökenli siyasetçi olması hem siyasette hem de dönem içinde gerçekleşen büyük savaşlarda bulunmasını ve görev almasını sağlamıştır. 1906 yılında İttihat ve Terakki Fırkası'na katılmasıyla başlayan siyaset yaşamı Milli Mücadele dönemi ile devam etmiş ve zaferden sonra da daha aktif bir biçimde siyaset sahnesine atılmışıtır. TCF'nin liderliği ile bunu pekiştirmiş̧ir. Lideri olduğu partisinin kapatılması ile siyaset yaşamı kısa bir süre daha devam eden Karabekir'in siyaset yaşamı İzmir suikast girişimi ile sekteye uğramış ve Atatürk'ün ölümüne kadar siyaset yaşamından uzak kalmıştır. Ancak bu durum kendisini ülke sorunlarından uzak durmasını engellememiş, yazdığı eserler ve gazetelere gönderdiği mektuplarla savunduğu düşüncelerini açıklamaktan geri durmamıştır. Mili Mücadele'nin en önemli simalarından olan Karabekir'in muhalefet saflarına geçmesinde kişisel ve ideolojik birçok etken bulunmaktadır. Sivas Kongresi ile başlayan görüş farklılıkları, yapılan inkılaplarla görüş ayrılıklarına dönüşmüş ve TCF’nin kurulması ile beraber Atatürk ile olan yol arkadaşlığı yol ayrımına dönüşmüştür.

Karabekir'in TCF'ye geçmesi ve lideri olmasının arkasında yatan nedenlerden bir tanesi, kendisinin Atatürk'ten sonra gelen en şöhretli komutanlardan birisi olmasıdır. Bu vasfı dolayısıyla Atatürk'e karşı denge unsuru olarak düşünülmüş, aynı zamanda ordudaki etkinliği nedeniyle ordunun desteğinin de alınması istenmiştir. Her ne kadar parti lideri olsa da partinin teşkilat yapısında yeteri kadar etkin olmamış bu görevi daha çok Ali Fuat Cebesoy ve Kara Vasıf Bey yürütmüştür. Meclis oturumlarında etkin olarak çalışmış ve basın yoluyla partisinin tanıtılmasına olabildiğince gayret göstermiştir. Ancak zaferden sonra hızla girişilen inkılap hareketleri, rejime karşı muhalefeti tahammülsüz kılması nedeniyle partisinin ömrü kısa sürmüş ve daha teşkilatlanmasını dahi

90 Kazım Karabekir, Çocuk davamız (İstanbul: Emre Yayınları, 1995), 300.

91 Kâzim Karabekir, Bir düello bir suikast (Istanbul: Emre, 1995), 153.

92 BCA: 030.10..0.0/ 45. 290. 41.

93 Semiz, "Atatürk ve Kâzım Karabekir Paşa", 208-9.

94 İsmet İnönü, Defterler, 1919-1973 (İstanbul: Yapı Kredi Yayınları, 2001), 258. 
tamamlayamadan kapatılmıştır. Bu yaşanan olaylar neticesinde Karabekir, lideri olduğu partiye tam olarak hâkim olamamış, adının ve şöhretinin etkisiyle parti vitrininde bulunmuştur.

Sonuç olarak partisi tanıtılması ve gelişmesi adına birçok gayretlerde bulunmasına rağmen partisinin kapatılmasını engelleyememiş, kendisi ve arkadaşlarının tasfiyesine mani olamamıştır. Kâzım Karabekir'in partideki etkinliği de parti ömrünün kısa olması hasebiyle uzun sürmemiştir. Ancak tüm bu yaşanan gelişmeler Karabekir'in kişiliğini ve Milli Mücadele'deki katkılarını gölgeleyememiştir. Türk dünyasına yaptığı katkılar ve Doğu Anadolu'daki yetim çocuklara sahip çıkması ve Doğu cephesindeki başarıları neticesinde Şark Fatihi olarak anılan Karabekir, tarihimizin önemli simalarından birisidir.

\section{Kaynakça}

Ahmad, Feroz. Ittihat ve Terakki: 1908 - 1914. 4. basım. Kaynak Yayınları. İstanbul: Kaynak Yayınlar1, 2004. 1998.

Akşin, Sina. Ana çizgileriyle Türkiye’nin yakın tarihi: 1789 - 1980. 6. bask1. Ankara: İmaj,

Arslan, Mukaddes. “MİLLİ MÜCADELE'DE KAZIM KARABEKİR PAŞA”, 2012, 8.

Atatürk. Nutuk. C. 1. Türk Tarih Kurumu Yayınları, 1999.

Atay, Falih Rıfkı. Çankaya: Atatürk’ün doğumundan ölümünekadar. Pozitif Yayınları Sosyal Tarih Dizisi. İstanbul: Pozitif Yayınları, 2004.

Aybars, Ergün. İstiklal Mahkemeleri. C. 1. 2 c. İzmir: İleri, 1995.

—. Türkiye Cumhuriyeti Tarihi. C. 1. İzmir: Zeus kitabevi yayınları, 2004.

Balcığlu, Mustafa. Direnen Millet-Milli Mücadele, Türkiye Cumhuriyeti Tarihi. C. 1. 2 c. Ankara: Atatürk Araştırma Merkezi Yayınları, 2011.

Cebesoy, Ali Fuat. Siyasi Hatıralar Büyük Zaferden Lozan'a Lozan'dan Cumhuriyete. İstanbul: Temel Yayınları, 2011.

Çavdar, Kazım. Kâzım Karabekir. İzmir: Sobe Matbaası, t.y.

Çiftçi, Ali. “Kâzım Karabekir'in Siyasal Hayatı”. Doktora Tezi, Ankara Üniversitesi Sosyal Bilimler Enstitüsü Kamu Yönetimi Anabilim Dalı, 2005.

Goloğlu, Mahmut. Türkiye Cumhuriyeti tarihi. İstanbul: Türkiye İş Bankası Kültür Yayınları, 2011.

Gürler, Hamdi. Paşaların gözüyle Milli Mücadele. 1. basım. Tarih dizisi 13. Kızılay, Ankara: Vadi Yayınları, 2015.

Güvercin, Özgür. "Terakkiperver Cumhuriyet Fırkasının Türk Siyasal Hayatındaki Yeri”. Yüksek Lisans, Abant İzzet Baysal Üniversitesi, Sosyal Bilimler Enstitüsü Tarih Ana Bilim Dalı, 2007.

İnönü, İsmet. Defterler, 1919-1973. İstanbul: Yap1 Kredi Yayınlar1, 2001.

Karabekir, Kazım. Birinci cihan harbini nasıl idare ettik? : Sarıkamış, Kars ve ötesi. İstanbul: Emre, 1994. 2003.

Karabekir, Kâzım. Bulgaristan Esareti ve Hatıralar Notlar. Tarih. İstanbul: Emre Yayınları, 
Karabekir, Kazım. Çocuk davamız. İstanbul: Emre Yayınları, 1995.

Karabekir, Kâzım. Hayatım. 1. baskı. Tarih. İstanbul: YKY, 2014.

—. Istiklâl Harbimiz. C. 1. İstanbul: Emre Yayınları, 2003. Ístiklâl Harbimiz. C. 2. İstanbul: Emre Yayınları, 2003.

Karabekir, Kazım. İstiklal Harbimizin Esasları(Yakllan Kitap). İstanbul: Sinan Matbaası ve Neşriyat Evi, 1972.

Karabekir, Kâzım. Ittihat ve Terakki Cemiyeti. 1. bask1. Tarih 48. İstanbul: YKY, 2014. Yayınlar1, 1994.

Kürt meselesi. Emre Yayınları Yakın Tarih serisi, 32 20. Cağaloğlu, İstanbul: Emre 1997. 1997.

. Nutuk ve Karabekir'den cevaplar. C. 6.7 c. Sultanahmet, İstanbul: Emre Yayınları,

—. Nutuk ve Karabekir'den cevaplar. C. 7.7 c. Sultanahmet, İstanbul: Emre Yayınları, —. Paşaların kavgası: inkilap hareketlerimiz. İstanbul: Emre Yayınları, 2000.

Karabekir, Kâzim. Bir düello bir suikast. Istanbul: Emre, 1995.

Karpat, Kemal H. Kısa Türkiye tarihi, 1800-2012. 1. baskı. Timaş yayınları. İstanbul: Timaş, 2012. 2012.

Karpat, Kemal H. Türk demokrasi tarihi [sosyal, kültürel, ekonomik temeller. Timaş: İstanbul,

Kılıç, Ali. Atatürk'ün sırdaşı: Kılıç Ali’nin anıları. 1. basım. Türkiye İş Bankası Kültür yayınları 409. İstanbul: Türkiye İş Bankası, 2005.

Kılıç, Sümer. İstiklal Mahkemeleri Adilmiydi(İzmir Suikasti İddianame ve Kazım Karabekir'in Savunmasi). İstanbul: Emre, 1994.

Kırzıoğlu, M. Fahrettin. Kâzım Karabekir: kendi eserleri, haltercümeleri ve Arşiv Belgeleri’ne göre. Kültür Bakanlığı yayınları; Türk büyükleri dizisi, 1278. 135. Ankara: Kültür Bakanlığı, 1991.

Mumcu, Uğur. Gazi Paşa'ya Suikast. İstanbul: Um:ag, 2010.

Okyar, Fethi. Üç Devirde Bir Adam. İstanbul: Tercüman, 1988.

Orbay, Hüseyin Rauf. Siyasi hatıralar. İstanbul: Örgün Yayınevi, 2009.

Özalper, Mehmet. "Bir Muhalefet Partisinin İlgası: Terakkiperver Cumhuriyet Firkası". Anemon Muş Alparslan Üniversitesi Sosyal Bilimler Dergisi 2, sy 1 (16 Mart 2015): 117-36.

Özçelik, Ayfer. Ali Fuat Cebesoy: 1882-10 Ocak 1968. Ankara: Akçağ, 1993.

Özdemir, Ali Ulvi. “Kazım Karabekir'in Muhalefete Geçişi ve Bu Süreçte Devlet Tarafından İzlenmesi", t.y., 33.

Sarıhan, Zeki. Kurtuluş Savaşı günlüğü: açıklamalı kronoloji. 1ci baskı. Türk Tarih Kurumu yayınları. Ankara: Öğretmen Dünyası, 1994.

Selek, Sabahattin. Anadolu ihtilali. C. 2. İstanbul: Kastaş Yayınları, 1987.

Semiz, Yaşar. “Atatürk ve Kâzım Karabekir Paşa”. Selçuk Üniversitesi Türkiyat Araştırmaları 
Dergisi, sy 4 (01 Aral1k 1997): 191-209.

Soysal, İsmail. Tarihçeleri ve açıklamaları ile birlikte: Türkiye’nin siyasal andlaşmaları. Ankara: Türk Tarih Kurumu Yayınları, 2000.

Stone, Norman. Birinci dünya savaşı. İstanbul: Doğan Kitap, 2010.

Tansü, Yunus Emre. “KAZIM KARABEKİR'İN DİPLOMAT KİŞİLİĞİ”. Social Sciences Studies Journal 4, sy 25 (01 Ocak 2018): 5448-57.

Tektosun, Mustafa. “Milli Mücadele Döneminde Doğu Cephesi”. Dicle Üniversitesi Sosyal Bilimler Enstitüsü Türkiye Cumhuriyeti Tarihi Bilim Dalı, 2007.

Turan, Şerafettin. Türk devrim tarihi. 1. basım. Yenişehir, Ankara : Cağaloğlu, İstanbul: Bilgi Yayınevi ; Bilgi Dağıtım, 2004.

Zürcher, Erik Jan. Cumhuriyet'in ilk yullarında siyasal muhalefet Terakkiperver Cumhuriyet Firkast (1924-1925) = Political opposition in the early Turkish Republic: the Progressive Republican Party, 1924-1925. İstanbul: İletişim, 2003. 